\title{
Predicting Land Cover Change in a Mediterranean Catchment at Different Time Scales
}

\author{
Hari Gobinda Roy, Dennis M. Fox*, and Karine Emsellem \\ UMR 7300 CNRS ESPACE, Université de Nice Sophia Antipolis, BP 3209, \\ 06204 Nice cedex 3, France \\ roy.hari.gobindaletu.unice.fr, \\ \{fox, Karine.Emsellem\}@unice.fr
}

\begin{abstract}
Land cover has been changing rapidly throughout the world, and this issue is important to researchers, urban planners, and ecologists for sustainable land cover planning for the future. Many modeling tools have been developed to explore and evaluate possible land cover scenarios in future and time scales vary greatly from one study to another. The main objective of this study is to test land cover change prediction at different time scales in a Mediterranean catchment in SE France. Land cover maps were created from aerial photographs $\left(1950,1982,2003,2008\right.$, and 2011) of the Giscle catchment $\left(235 \mathrm{Km}^{2}\right)$ and surfaces were classified into four land cover categories: forest, vineyard, grassland, and built area. Explanatory variables were selected through Cramer's coefficient. Different time scales were tested in the study: short (2003-2008), intermediate (1982-2003), and long (1950-1982). To test the model's accuracy, Land Change Modeler (LCM) of IDRISI was used to predict land cover in 2011 and predicted images were compared to a real 2011 map. Kappa index and confusion matrix were used to evaluate the model's accuracy. Altitude, slope, and distance from roads had the greatest impact on land cover changes among all variables tested. Good to perfect level of spatial and perfect level of quantitative agreement were observed in long to short time scale simulations. Kappa indices $\left(K_{\text {quantity }}=0.99\right.$ and $\left.K_{\text {location }}=0.90\right)$ and confusion matrices were good for intermediate and best for short time scale. The results indicate that shorter time scales produce better predictions. Time scale effects have strong interactions with specific land cover dynamics, in which stable land covers are easier to predict than cases of rapid change and quantity is easier to predict than location for longer time periods.
\end{abstract}

Keywords: Time scale, Land cover change modeling, Mediterranean Europe, Land change Modeler (LCM).

\section{Introduction}

\subsection{Land Cover Change Modeling}

Land cover is changing rapidly throughout the world, and it has become an important issue for urban planners, ecologists, economists, and resource managers to evaluate

\footnotetext{
* Corresponding author.
} 
environmental change and establish sustainable development planning [7, 10, 17]. Land cover change models are able to identify location and quantity of change, predict land cover change considering past changes, test explanatory variables, and simulate management policies. For this reason, many interdisciplinary research projects have been initiated for land cover change modeling, measuring regional and global land cover change, forecasting future conditions, and planning for sustainable development [28]. As a result, researchers have created a large set of operational modeling tools to implement prediction and exploration of possible land cover change trajectories and land cover planning and policy in recent years [29]. Moreover, land cover change, urban growth, and spatial modeling have drawn considerable interest in the last two decades due to better computing power, availability of spatial data, and the need for innovative planning tools for decision support [7]. Advanced urban and land cover change modeling techniques have been included in many GIS software package.

\subsection{The Role of Time Scale in Land Change Prediction}

The selection of prediction and validation time intervals has a great impact on prediction accuracy [6]. Prediction accuracy can depend on the rate and process of transitions in both time intervals. Modeling of land cover change using a coarser temporal scale may fail to understand landscape change patterns properly and can hamper model performance [2], so most studies on future land cover change use short to intermediate historical time scales (5-15 years). Many studies on urban land cover change modeling use short time scales that achieve better prediction [1, 11, 18, 24]. Some studies use intermediate time scales [13, 14, 15, 20, 25, 26, 27] and very few studies use long time scales to simulate urban land cover [4] and multiple land cover change $[10,21]$. Average historical and prediction time periods are about 10 and 12 years, respectively, analyzing 25 recent studies on land cover change using CA-Markov and Multi-Layer Perceptron (MLP).

Very few studies were found on the comparison of the impact of historical time periods on land cover prediction using different time scales. To investigate the impact of time interval on prediction accuracy in Gorizia-Nova Gorica (Italy), urban area was predicted for different years (2005 to 2010) from initial conditions in 1985 and 2004 [5]. The authors found that prediction accuracy increased with decreasing prediction time period.

\subsection{Objectives}

The objective of this paper is to explore the impact of temporal scales on land cover change modeling for predicting land cover change in a Mediterranean catchment in SE France. Land cover maps of 2011 were predicted from different time scales (19501982, 1982-2003, and 2003-2008) and compared with the digitized land cover map of 2011 to measure model accuracy. The study is part of a larger program to evaluate the impacts of land cover change on runoff and soil erosion at the catchment scale. 


\section{Methods}

Study area, land change modeling steps, and data are discussed in this section.

\subsection{Site Description}

The study area (about $235 \mathrm{~km}^{2}$ ) is situated in the Var department of SE France near the Gulf of St. Tropez. The western part of the watershed (about $70 \%$ of the catchment) is forest (mostly pine and oaks), and the topography is uneven with the highest elevation at about $650 \mathrm{~m}$. The lower part of the catchment is a gently sloping alluvial plain. The catchment area is characterized by a Mediterranean climate with hot dry summers, and cooler rainier winters. Average temperatures range between $22^{\circ} \mathrm{C}$ to $26^{\circ} \mathrm{C}$ in summer and $5^{\circ} \mathrm{C}$ to $10^{\circ} \mathrm{C}$ in winter. The mean annual rainfall is about 900 $\mathrm{mm}$, and the main rainy season is from October to January [9]. Several tributaries flow into the Giscle main channel, including the Môle, the Grenouille, the Tourre, and the Verne. Three main municipalities are located within the catchment: Cogolin, Grimaud, and La Môle.

\subsection{Land Change Modeling Procedure}

Land Change Modeler (LCM) in IDRISI [8] was originally designed to manage impacts on biodiversity, and analyze and predict land use and land cover changes. Only thematic raster images with the same land cover categories listed in the same sequential order can be inputted in LCM for analysis, and background areas must be identified on maps coded with 0. LCM evaluates land cover changes between Time 1 (initial time) and Time 2 (second time). It calculates the changes, and displays the results with various graphs and maps. Finally, it predicts future (Time 3) land cover on the basis of relative transition potential maps. LCM was used in this study to identify explanatory variables, create transition potentials, and predict future land cover maps.

\section{Digital Data and Land Cover Categories}

Land cover maps were digitized from grey scale ortho-rectified aerial photographs of 1950 and 1982, and color ortho-photos of 2003, 2008, and 2011. Spatial resolution for all aerial photographs was reduced to $1 \mathrm{~m}$ from $0.5 \mathrm{~m}$ to facilitate data manipulation during digitization. Surfaces were initially characterized into five categories: forest $(F)$, vineyard $(\mathrm{V})$, grassland $(\mathrm{G})$, urban $(\mathrm{U})$ and suburban $(\mathrm{S})$, but the last 2 categories were collapsed into a single built area (B) class to improve category attribution as described below. Methods of land cover digitization, classification, and characteristics of land cover classes were discussed in [23]. Land cover classification was facilitated by numerous field visits, and validation was carried out through a group of 15 third year Geography students of the University of Nice Sophia Antipolis. Each student was provided with a sample of 20 selected cells to identify land cover class; each sample had a roughly equal number of cells in each category, and there were 5 
students for each year (1950, 1982, and 2003). This was the students' first contact with digital air photos, so the validation is considered a worst case scenario.

Slope was created from a 25 m Digital Elevation Model (DEM). Road and stream networks were screen digitized from the aerial photographs of 2008. Only major roads were taken into account, so road network was considered constant for all time periods. In order to make the land cover maps compatible with the explanatory variables, celle size was converted to $25 \mathrm{~m}$.

\section{Explanatory Variables and Constraints}

Topographic and distance variables have been used to simulate land cover change studies throughout the world [16, 18, 19, 27]. In an earlier study [23], major topographic and distance variables were identified. These include the following: slope, altitude, distance from roads, distance from built area (initial year), and distance from streams. In addition, three constraints and incentives (forest to built area, vineyard to built area, and grassland to built area) were included in the prediction process. These were created from the "Plan Local d'Urbanisme" (PLU) and "Schéma de Coherence Terrtoriale" (SCOT). The PLU is the local urban plan in France; it determines land use guidelines. The SCOT integrates different policies regarding urban planning: social and private housing, communication infrastructure and public transport, commercial infrastructure, and environment protection. Constraints and incentives are multiplied by the corresponding transition potential during modeling. In this study, values of 0 on the map were used to define absolute constraint, and 1.1 was used for incentives to emphasize the expansion of built areas in suitable selected zones for development according to the regional plan. In addition, distance from streams was also added with above mentioned constraints. Disincentive areas situated within a distance from streams of 0-25 m, and 25-50 m were defined by values of 0.6 and 0.8, respectively to maintain the historical trend of less urbanization near stream networks in the study area according to [23].

\section{Selection of Explanatory Variables}

The simulation of multiple categories of land cover change depends on several explanatory variables [18]. Explanatory variables that were drivers of past land cover change are expected to be an influential force in future changes and are selected based on available data and their explanatory abilities. DEM, slope, and distance from road represent the accessibility of a neighborhood, and distance from built area highlights the proximate location of urbanization. The significance of explanatory variables was tested using Cramer's V which measures the strength of association between two categorical variables based on Chi-square statistics [21]. In this study, land cover change in a historical time period and explanatory variables are taken into account to test Cramer's V for a particular variable. LCM calculates Cramer's V automatically and displays the association level of explanatory variables with land cover categories. Variables with greater values are considered more important than other variables. Cramer's V values of $\geq 0.4$ and $\geq 0.15$ are considered good and useful, respectively; and values $<0.15$ should be removed from the model [8]. 


\section{Transition Potentials}

Transition potential maps were created for each transition possibility ( $\mathrm{F}$ to $\mathrm{V}, \mathrm{F}$ to $\mathrm{G}$, F to $B, V$ to $F, V$ to $G, V$ to $B, G$ to $F, G$ to $V$, and $G$ to B) based on historical changes and selected explanatory variables. The Multi-Layer Perceptron Neural Network (MLPNN) algorithm of IDRISI [8] was employed to create transition potentials. Each transition potential was modeled individually using the same explanatory variables, but only transition potentials with an accuracy rate greater than $70 \%$ were utilized for land cover prediction.

\section{Land Cover Prediction and Time Scales Test}

Land cover change prediction has two aspects: the quantity of change is provided by the Markov change model matrix and the spatial distribution of change is given by MLPNN. LCM provides the quantity of change by evaluating the Markov matrix comparing the initial (T1) and second land cover (T2), and then predicts the future land cover (T3) using a transition probability matrix for the future. The transition probability matrix displays the probability of each land cover category changing into another category. A value close to 0 indicates a low conversion probability, and 1 indicates a high conversion probability for the target land cover. Land cover maps were predicted for 2011 using transition potential maps from several historical time periods (1950-1982, 1982-2003, 2003-2008) (Table 1). The same variables and constraints were incorporated in all simulations.

Table 1. Historical time periods, prediction and validation dates for different scales

\begin{tabular}{|c|c|c|c|}
\hline $\begin{array}{c}\text { Historical time } \\
\text { period }\end{array}$ & $\begin{array}{c}\text { Prediction } \\
\text { date }\end{array}$ & $\begin{array}{c}\text { Historical time } \\
\text { interval }\end{array}$ & $\begin{array}{c}\text { Validation time } \\
\text { interval }\end{array}$ \\
\hline $1950-1982$ & 2011 & 32 & 29 \\
\hline $1982-2003$ & 2011 & 21 & 8 \\
\hline $2003-2008$ & 2011 & 5 & 3 \\
\hline
\end{tabular}

\section{Land Cover Prediction Validation}

Validation of a model is needed in order to assess its accuracy. To do this, simulated land cover maps of 2011 created using different time scales were compared with a digitized map of the same year. Kappa indices and error matrix analysis were used in the study for model validation. The standard 'Kappa index' is a comparative analytical process that measures spatial and non-spatial aspects between predicted and reference maps [8]. Kappa values were characterized as excellent over $0.75,0.40$ to 0.75 as fair to good, and below 0.40 as poor [8].

Several components of Kappa indices are described in [22]: Kappa standard ( $\mathrm{K}_{\text {stan- }}$ dard), Kappa for location $\left(\mathrm{K}_{\text {location }}\right)$, and Kappa for quantity $\left(\mathrm{K}_{\text {quantity }}\right)$. They [22] define " $K_{\text {standard }}$ as an index of agreement that attempts to account for the expected agreement due to random spatial reallocation of the categories in the comparison map, given the proportions of the categories in the comparison and reference maps, regardless of the size of the quantity disagreement". $\mathrm{K}_{\text {quantity }}$ is a ratio of quantitative difference between the categories in the comparison map and reference map, and $\mathrm{K}_{\text {location }}$ is the spatial allocation agreement between them. 
The confusion matrix was analyzed using the ERRMAT module of IDRISI [8] to assess the fitness of spatial cell allocation between predicted and true values. ERRMAT outputs an error matrix containing a tabulation of the number of cells found in each possible combination of true and mapped categories and a summary of statistics [8]. Error of omission estimates the proportion of the area of a particular land cover that is omitted by the model. Error of commission represents the proportion of wrongly attributed land cover of a particular category that is overestimated by the model for each category.

\section{Results}

\subsection{Land Cover Change Analysis during Different Time Periods}

The classification validation procedure revealed that classifying land cover into five categories was difficult from grey scale photographs and simpler for the 2003 color air photos. For 1950, classification error was $27 \%$, and sources of error were either a confusion between vineyard and grassland or urban and suburban. The classification error decreased to $20 \%$ when urban and suburban were collapsed into a single built category. For 1982, category error was $10 \%$ and $20 \%$ for 4 and 5 categories, respectively. Finally, for 2003, the error was only $4 \%$ for 4 categories, down from an initial $15 \%$ due to confusion between urban and suburban classes (by one student). It should be noted that the exercise was for unexperienced undergraduates just introduced to digital air photos. The actual classification was carried out by an experienced user over several months and verified thoroughly by a second experienced user, so the actual classification accuracy can be considered much greater than the values cited above.

Fig. 1a-d show land cover maps (1950, 1982, 2003, and 2008) digitized from the air photos. Most of the land cover changes occurred in the alluvial plain (East), where most of the vineyard, grassland and built areas are concentrated.

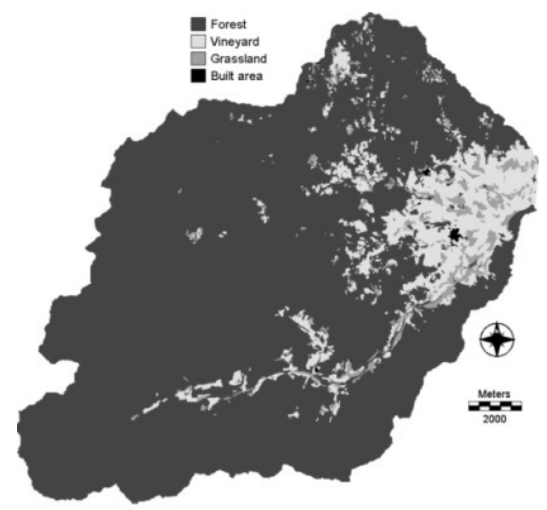

Fig. 1a. Land cover map of 1950

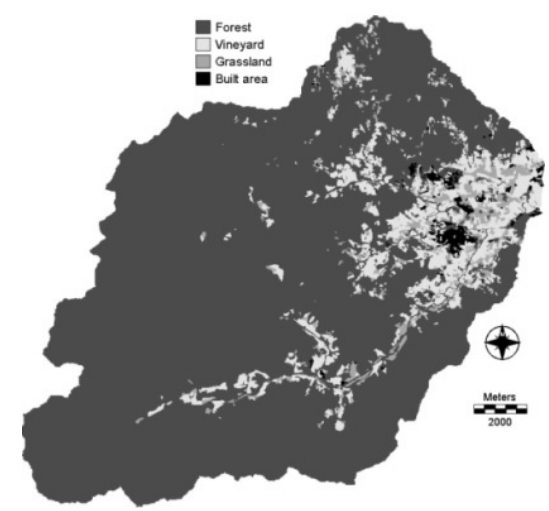

Fig. 1b. Land cover map of 1982 


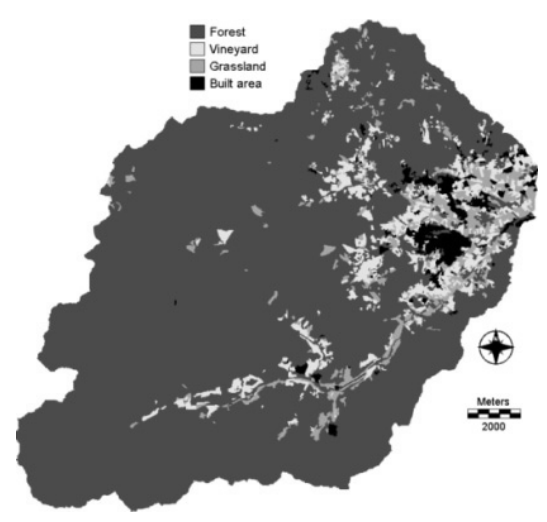

Fig. 1c. Land cover map of 2003

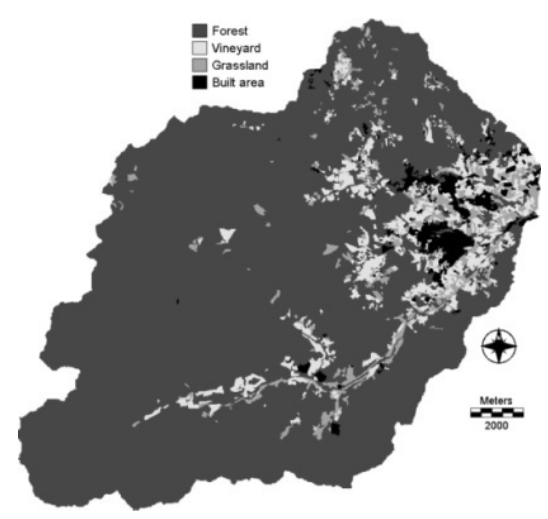

Fig. 1d. Land cover map of 2008

Fig. 2 a-d present land cover changes (ha) in all categories of the study area, and Table 2 shows the percentage of total surface area of each land cover category in different years. Two general trends can be identified in land cover change since 1950: forest and vineyard decreased while grassland and built area increased. Some changes in forest occurred in 1982-2003 as it lost about 120 ha (Fig. 2 a). A marked decrease was observed in vineyard (28\% of the initial year) that lost 854 ha between 1950 and 2003 (Fig. 2 b). Then, it increased 67 ha in 2003-2008 and resumed its decreasing trend in the last time period 2008-2011. Vineyard was $10.4 \%$ of the catchment in 1950 and decreased to $6.6 \%$ in 2003 and then remained more or less stable till 2011. Grassland increased from $3.4 \%$ to $5.4 \%$ of the catchment in 1950-2003 and decreased slightly to $4.9 \%$ in 2011 . It increased greatly (383 ha) in 1982-2003, decreased 122 ha in the next time period (2003-2008) but resumed the increasing trend again in 2008-2011 (Fig. 2 c). Built area remained a minor component of the catchment, and increased rapidly from only $0.1 \%$ to $3.2 \%$ of the catchment during the study period (Table 2).

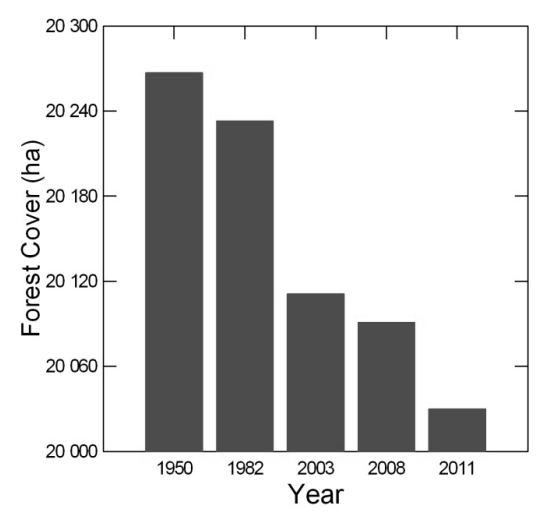

Fig. 2a. Forest change in 1950-2011

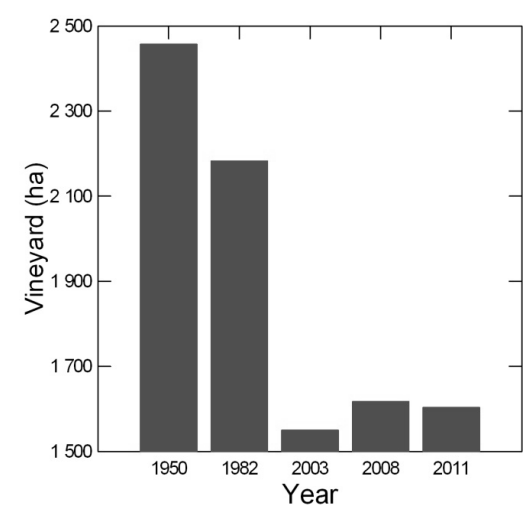

Fig. 2b. Vineyard change in 1950-2011 


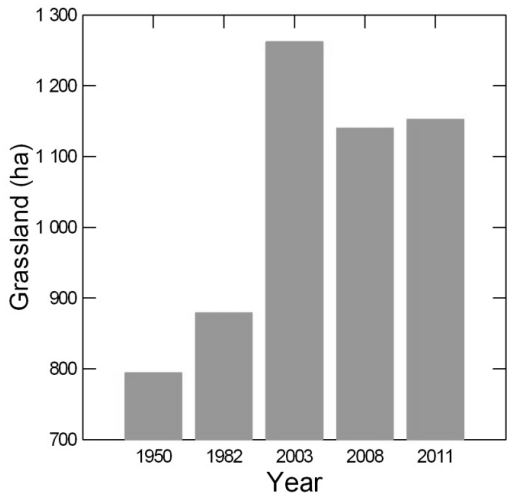

Fig. 2c. Grassland change in 1950-2011

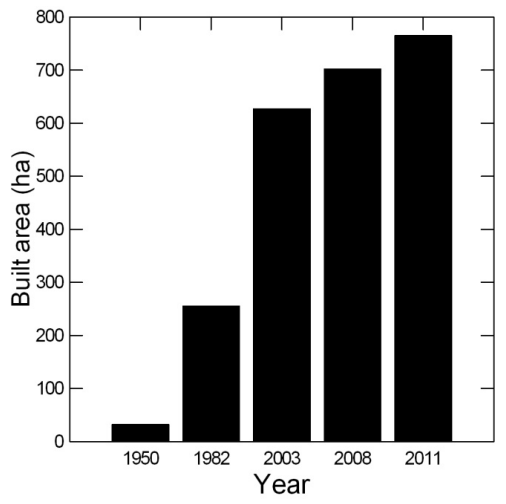

Fig. 2d. Built area change in 1950-2011

Table 2. Percentage of the catchment area for each category

\begin{tabular}{|c|c|c|c|c|c|}
\hline & \multicolumn{5}{|c|}{ Total surface area (\% of the catchment) } \\
\hline & 1950 & 1982 & 2003 & 2008 & 2011 \\
\hline Forest & 86.1 & 85.9 & 85.4 & 85.3 & 85.1 \\
\hline Vineyard & 10.4 & 9.3 & 6.6 & 6.9 & 6.8 \\
\hline Grassland & 3.4 & 3.7 & 5.4 & 4.8 & 4.9 \\
\hline Built area & 0.1 & 1.1 & 2.7 & 3.0 & 3.2 \\
\hline
\end{tabular}

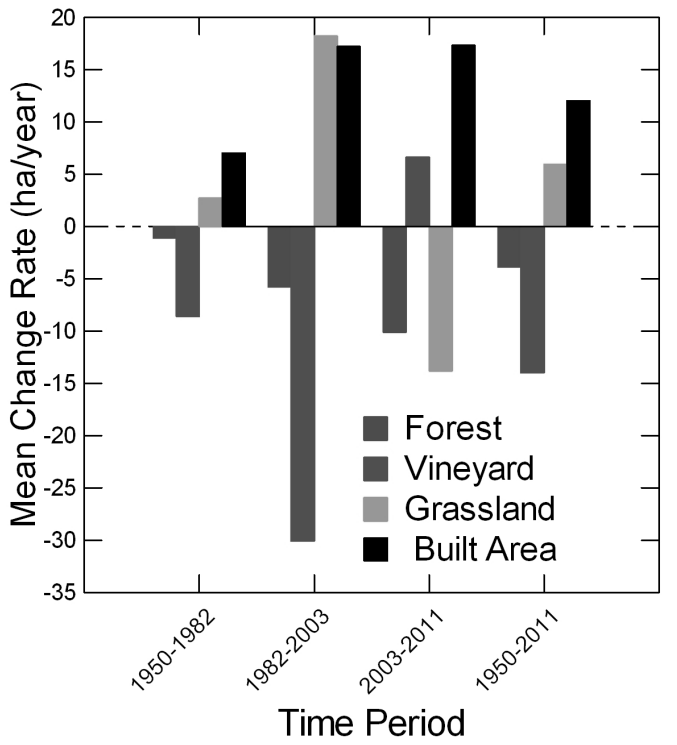

Fig. 3. Mean rates of land cover change (ha) in different time periods 
Fig. 3 summarizes the mean rate of change of each land cover category in the dif-

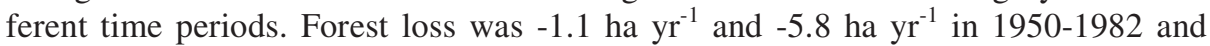

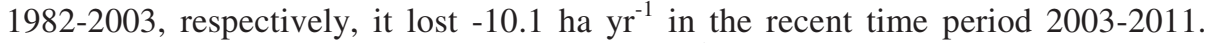

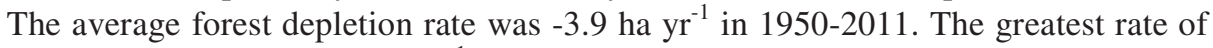

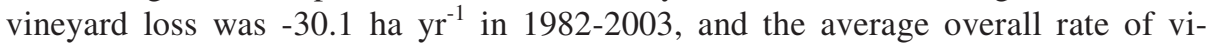

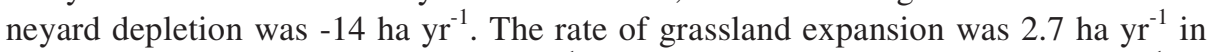

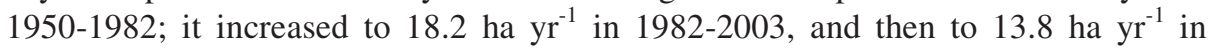

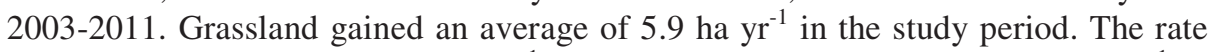

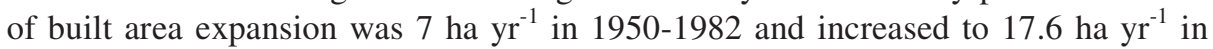
the recent time period 2003-2011. So, the average rate of built area expansion was 12 ha $\mathrm{yr}^{-1}$ in $1950-2011$.

\subsection{Selection of Explanatory Variables}

The association level between explanatory variables and land cover types in different time periods is shown in Table 3. It is measured through Cramer's V. All variables have a Cramer's V value $\geq 0.15$ with all land cover types except forest in the long time period (1950-1982).

Table 3. Cramer's V coefficient (relationship between land cover change and explanatory variables). Values $\geq 0.40$ are highlighted in bold

\begin{tabular}{|c|c|c|c|c|c|c|}
\hline $\begin{array}{c}\text { Time } \\
\text { period }\end{array}$ & Altitude & Slope & $\begin{array}{c}\text { Dist. } \\
\text { Road }\end{array}$ & $\begin{array}{c}\text { Dist. Built } \\
\text { area }\end{array}$ & $\begin{array}{c}\text { Dist. } \\
\text { stream }\end{array}$ \\
\hline \multirow{3}{*}{ 1950-1982 } & Forest & 0.20 & 0.15 & 0.31 & $\mathbf{0 . 4 0}$ & 0.12 \\
\cline { 2 - 7 } & Vineyard & $\mathbf{0 . 6 9}$ & $\mathbf{0 . 6 5}$ & $\mathbf{0 . 5 9}$ & $\mathbf{0 . 4 6}$ & $\mathbf{0 . 4 1}$ \\
\cline { 2 - 7 } & Grassland & $\mathbf{0 . 5 2}$ & $\mathbf{0 . 5 0}$ & $\mathbf{0 . 4 4}$ & 0.33 & 0.32 \\
\cline { 2 - 7 } 1982-2003 & Built area & 0.39 & 0.36 & 0.28 & 0.22 & 0.20 \\
\cline { 2 - 7 } & Forest & 0.30 & 0.22 & $\mathbf{0 . 4 9}$ & $\mathbf{0 . 6 0}$ & 0.16 \\
\cline { 2 - 7 } & Vineyard & $\mathbf{0 . 6 7}$ & $\mathbf{0 . 6 3}$ & $\mathbf{0 . 5 9}$ & $\mathbf{0 . 5 9}$ & $\mathbf{0 . 4 1}$ \\
\cline { 2 - 7 } & Grassland & $\mathbf{0 . 4 0}$ & $\mathbf{0 . 4 0}$ & 0.36 & 0.33 & 0.27 \\
\cline { 2 - 7 } 2003-2008 & Built area & $\mathbf{0 . 4 4}$ & $\mathbf{0 . 4 2}$ & 0.30 & 0.30 & 0.25 \\
\cline { 2 - 7 } & Forest & 0.30 & 0.22 & $\mathbf{0 . 4 9}$ & $\mathbf{0 . 6 4}$ & 0.16 \\
\cline { 2 - 7 } & Vineyard & $\mathbf{0 . 6 7}$ & $\mathbf{0 . 6 2}$ & $\mathbf{0 . 5 9}$ & $\mathbf{0 . 6 0}$ & $\mathbf{0 . 4 1}$ \\
\cline { 2 - 7 } & Grassland & $\mathbf{0 . 4 1}$ & $\mathbf{0 . 4 1}$ & 0.36 & 0.34 & 0.27 \\
\cline { 2 - 7 } & Built area & 0.39 & 0.38 & 0.27 & 0.29 & 0.25 \\
\hline
\end{tabular}

The strongest explanatory variable is altitude, which has a good association level (Cramer $\mathrm{V} \geq 0.40$ ) with all land covers except forest for all time periods. A good association level is also observed in slope with all land covers in all time periods, especially with vineyard and grassland. Distance from roads shows a high association level with vineyard in all time periods, and has good association level with forest and grassland in the intermediate (1982-2003) and long (1950-1982) time periods, respectively. Distance from built area also has a good association level with forest and vineyard in all time periods. Distance from streams is the weakest variable; it shows comparatively limited association with existing land covers and has only a good level of association with vineyard in all time periods. The lowest association is observed 
for forest with all variables except distances from road and built area, indicating that the dominant forest category (about $85 \%$ ) is less influenced by topographic variables.

\subsection{Transition Potentials}

Transition potentials for different time periods present similar patterns and the same explanatory variables were used in all simulations for the different time scales. Table 4 presents the accuracy rate of all transition potentials for different time periods. Accuracy rate represents the agreement between a particular transition and selected explanatory variables. A high accuracy rate is observed for several transitions in all time periods: forest to all other categories, and vineyard and grassland to built area. Transition from vineyard to forest in 2003-2008 also shows high accuracy. Therefore, transition potentials from forest to all and vineyard and grassland to built area are good. All transitions from vineyard and grassland to other land covers except built area have low to intermediate accuracy rate.

Table 4. Accuracy rate (\%) of transition potentials in different time periods (F-Forest, V-Vineyard, G-Grassland, B-Built area)

\begin{tabular}{|c|c|c|c|c|c|c|c|c|c|}
\hline & \multicolumn{10}{|c|}{ Accuracy rate (\%) } \\
\hline Time period & F-V & F-G & F-B & V-F & V-G & V-B & G-F & G-V & G-B \\
\hline $\mathbf{1 9 5 0 - 1 9 8 2}$ & 85 & 86 & 99 & 64 & 58 & 97 & 63 & 58 & 97 \\
\hline $\mathbf{1 9 8 2 - 2 0 0 3}$ & 83 & 81 & 97 & 64 & 60 & 85 & 62 & 57 & 83 \\
\hline $\mathbf{2 0 0 3 - 2 0 0 8}$ & 91 & 97 & 98 & 100 & 63 & 85 & 63 & 64 & 82 \\
\hline
\end{tabular}

\subsection{Validation of Predicted Land Cover}

Simulations for 2011 were executed using transition potentials from 1950-1982, 1982-2003, and 2003-2008, respectively. Simulated and actual land cover maps of 2011 are presented in Fig. 4a-d. Dissimilarities are observed mainly in the plain land

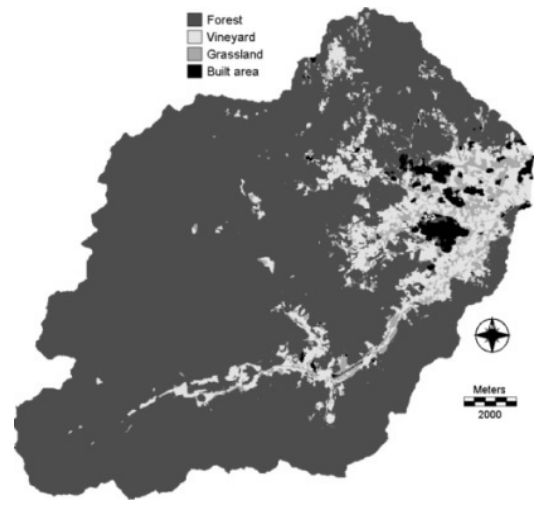

Fig. 4a. Predicted land cover map of 2011 from transition potentials 1950-1982

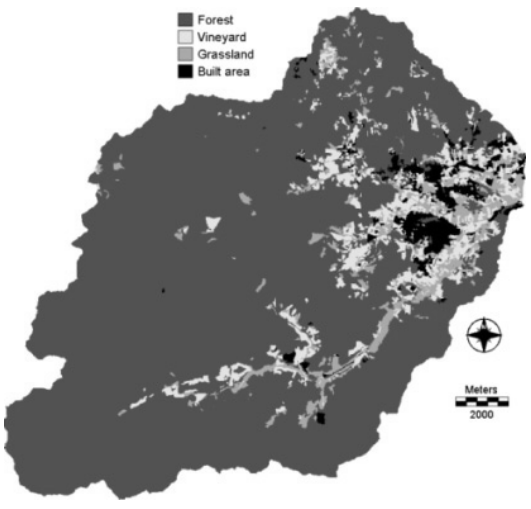

Fig. 4b. Predicted land cover map of 2011 from transition potentials 1982-2003 


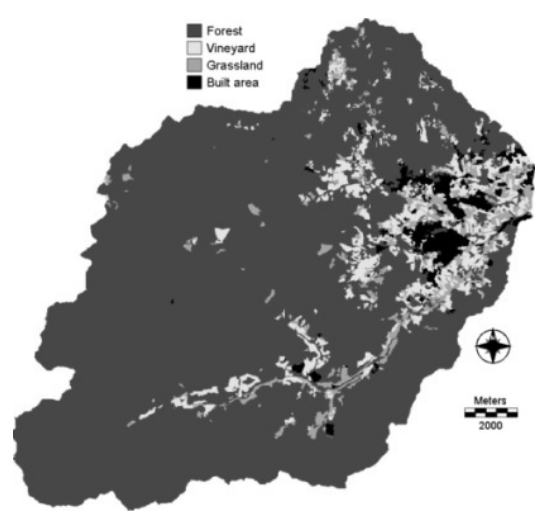

Fig. 4c. Predicted land cover map of 2011 from transition potentials 2003-2008

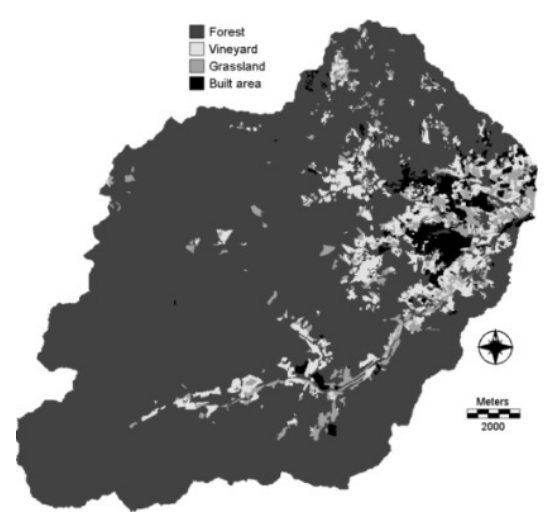

Fig. 4d. Land cover map 2011 (actual)

of the eastern part of the catchment where most of the conversion took place as described in [23]. Visual interpretation (Fig. 4 a-c) suggests the simulated maps from intermediate (Fig. 4 b) and short (Fig. 4 c) time scales are reasonably similar to the actual map of that year (Fig. 4 d).

\section{Kappa Indices for Predicted Land Cover from Different Time Periods}

The summary of the Kappa indices at different time scale simulations is presented in Table 5. These indices are acquired from the VALIDATION module of IDRISI [8] and can also be obtained using the Pontius matrix following [22]. Results show that all Kappa components increase with decreasing time scale up to the near perfect level of agreement for the short time scale. However, simulation from long time scale also achieved a perfect level for $\mathrm{K}_{\text {quantity }}$ and a reasonable level of agreement for $\mathrm{K}_{\text {location, }}$, and $\mathrm{K}_{\text {standard}}$.

Values of $\mathrm{K}_{\text {quantity }}$ were observed in the perfect level of agreement in all three simulations, and these values increased a little from 0.95 to 1.00 for long to short time scale simulations. $\mathrm{K}_{\text {location }}$ gives the overall spatial accuracy of a simulation. Spatial accuracy was difficult to achieve from the long time simulation. Values of $\mathrm{K}_{\text {location }}$ varied greatly from long to short time scale though the simulation for the long time scale also had a good level of agreement (0.75); this increased to 0.87 and 0.94 for intermediate and short time simulations, respectively. The greatest changes were also observed in $\mathrm{K}_{\text {standard }}$ for different time scales which increased from 0.66 to 0.94 with decreasing time scale.

Table 5. Summary of Kappa indices

\begin{tabular}{|c|c|c|c|}
\hline & \multicolumn{3}{|c|}{ Initial time period } \\
\hline & $1950-1982$ & $1982-2003$ & $2003-2008$ \\
\hline $\mathrm{K}_{\text {quantity }}$ & 0.95 & 0.99 & 1.00 \\
\hline $\mathrm{K}_{\text {location }}$ & 0.75 & 0.90 & 0.94 \\
\hline $\mathrm{K}_{\text {standard }}$ & 0.66 & 0.87 & 0.94 \\
\hline
\end{tabular}




\section{Error Matrix Analysis for Predicted Land Cover from Different Time Periods}

Table 6 presents the error matrix analysis of the actual land cover map 2011 (column) against predicted land cover (row) for different time scales. The table contains three 6 x 6 matrices for the 1950-1982, 1982-2003, and 2003-2008 time periods. In addition to overall errors, this table also shows where errors occur. For example, 158 ha of vineyard was wrongly attributed to forest, and 438 ha of vineyard was omitted that should be forest.

Table 6. Error matrix analysis of actual land cover map 2011 (column) against predicted (row) land cover from transition potentials for different time periods. Values are expressed in hectares (ha) and errors of commission and omission are expressed in \% and in bold.

\begin{tabular}{|c|c|c|c|c|c|c|c|}
\hline $\begin{array}{c}\text { Initial time } \\
\text { period }\end{array}$ & & Forest & Vineyard & Grassland & $\begin{array}{c}\text { Built } \\
\text { area }\end{array}$ & Total & $\begin{array}{c}\text { Error of com- } \\
\text { mission }(\%)\end{array}$ \\
\hline \multirow{6}{*}{$\begin{array}{l}\text { 1950-1982 } \\
\text { (long) }\end{array}$} & Forest & 19,277 & 158 & 236 & 113 & 19,784 & 2.6 \\
\hline & Vineyard & 438 & 1,305 & 488 & 156 & 2,387 & 45.3 \\
\hline & Grassland & 295 & 113 & 403 & 118 & 930 & 56.6 \\
\hline & Built area & 20 & 27 & 25 & 378 & 450 & 16.0 \\
\hline & Total & 20,030 & 1,603 & 1,152 & 765 & 23,550 & \\
\hline & $\begin{array}{c}\text { Error of } \\
\text { Omission }(\%) \\
\end{array}$ & 3.8 & 18.6 & 65.0 & 50.6 & & 9.3 \\
\hline \multirow{6}{*}{$\begin{array}{c}\text { 1982-2003 } \\
\text { (interme- } \\
\text { diate) }\end{array}$} & Forest & 19,716 & 45 & 52 & 51 & 19,864 & 0.7 \\
\hline & Vineyard & 68 & 1,413 & 80 & 30 & 1,590 & 11.2 \\
\hline & Grassland & 204 & 119 & 965 & 37 & 1,326 & 27.2 \\
\hline & Built area & 42 & 26 & 54 & 647 & 770 & 15.9 \\
\hline & Total & 20,030 & 1,603 & 1,152 & 765 & 23,550 & \\
\hline & $\begin{array}{c}\text { Error of } \\
\text { Omission }(\%)\end{array}$ & 1.6 & 11.9 & 16.2 & 15.4 & & 3.4 \\
\hline \multirow{6}{*}{$\begin{array}{l}\text { 2003-2008 } \\
\quad \text { (short) }\end{array}$} & Forest & 19,953 & 30 & 45 & 27 & 20,055 & 0.5 \\
\hline & Vineyard & 16 & 1,496 & 94 & 15 & 1,621 & 7.7 \\
\hline & Grassland & 44 & 68 & 997 & 17 & 1,127 & 11.5 \\
\hline & Built area & 16 & 9 & 16 & 706 & 747 & 5.4 \\
\hline & Total & 20,030 & 1,603 & 1,152 & 765 & 23,550 & \\
\hline & $\begin{array}{c}\text { Error of } \\
\text { Omission }(\%)\end{array}$ & 0.4 & 6.7 & 13.4 & 7.7 & & 1.69 \\
\hline
\end{tabular}

Errors for all land covers decreased with decreasing time scales. The lowest commission and omission errors were observed in forest for all time scales and these decreased slightly with decreasing time scales. Errors of commission and omission were $2.6 \%$ and $3.8 \%$, respectively, for forest in the long time scale prediction, and these decreased to $0.7 \%$ and $1.6 \%$ in the intermediate and $0.5 \%$ and $0.4 \%$ in the short time scale predictions, respectively. High error of commission $(45.3 \%)$ was observed in vineyard in the long time scale where the greatest amount of vineyard (1,082 ha) was wrongly attributed, and commission error decreased markedly in intermediate and short time scales. However, error of omission was relatively low in the long time scale simulation for vineyard. The highest errors of commission and omission were observed in grassland in all time scale simulations, particularly the long time scale where errors of commission and omission were $56.6 \%$ and $65 \%$, respectively. Errors for this land cover also decreased greatly with decreasing time scale (Table 6). Considerable amounts of vineyard and grassland were wrongly attributed to forest, and considerable areas of vineyard and grassland were omitted by the model in the long 
time scale simulation; this occurred mainly due to high swapping of these land covers with forest. For this reason, high errors of commission and omission were generated for vineyard and grassland in the long time scale; errors decreased considerably in the intermediate and short time scale simulations. In long time simulation, errors of commission of built area were lower than for vineyard and grassland due to its small coverage in the catchment, and it was wrongly attributed 72 ha of other land covers. However, high error of omission was observed in the same simulation because much built area (388 ha) was omitted.

\section{Discussion}

Land cover dynamics and changes in individual land covers have an important impact on land cover simulation. As it is described in the results, forest is easy to predict, and it obtains the best level of agreement and the lowest error in all simulations using different time scales due to its dominant coverage in the study area. It is the least probable to change in all transition potentials of forest to other land covers, so $\mathrm{K}_{\text {quantity }}$ is better for all time scales.

Simulations of vineyard and grassland are extremely difficult to predict: accuracy is lower and errors greater due to the dynamic changes in different time periods and high swapping between these covers. Hence, high commission and omission errors are observed in vineyard and grassland simulations, particularly in the long time scale. These errors may occur due to different rates of change in initial and prediction time periods and the selection of transition potentials where transition potentials from vineyard to forest and grassland, and grassland to forest and vineyard were avoided due to their limited accuracy rate $(<70 \%)$. Simulations of vineyard and grassland may improve using constraints for vineyard and grassland. Vineyard fields belonging to the wine making "domaines" tend to remain stable and convert to other covers less [23], so a "domaine" layer could be used as a constraint for vineyard. This information, however, was not available in this study. In addition, fire breaks, horseback riding, and other tourism related activity zones that are classified as grassland could perhaps be taken as a constraint for grassland.

Accurate prediction of urban expansion is difficult due to the complexity in urbanization which depends on several spatial variables, urban planning, and land use demand [12]. The rapid relative rate of urban growth impacted the urban prediction. For example, the model predicts (for 2011) about $40 \%$ less built area than the actual map of 2011 using the long time scale because the rate of built area expansion increased by more than double in the latter time period (1982-2011) compared to the initial period (1950-1982) (Fig. 3). However, intermediate and short time periods perform better since increasing trends in the initial time periods are about the same as in the prediction time periods (2003-2011 and 2008-2011). In addition, several scattered urban areas are developed exceptionally far away from existing built area in the recent year, and these remain difficult to predict because the model is based on historical trends. Earlier trials showed the use of constraints for the transitions to built area from other land covers reduced error in built area in all simulations. 
Time scales have a significant impact on land cover simulation. Quantity was predicted better than location, probably due to the dominant forest cover in the study area. Therefore, $\mathrm{K}_{\text {quantity }}$ is nearly perfect in all time scales. However, complex land cover changes and swapping between land covers generate less perfect levels of agreement for $\mathrm{K}_{\text {location }}$ than $\mathrm{K}_{\text {quantity }}$, and values increase with decreasing time scales.

Although different indexes are used, there is a general trend for Shorter time scales to Produce better prediction results [1, 15, 16, 20, 21, 24, and 27], as found in this study was. The values of $\mathrm{K}_{\text {quantity }}$ and $\mathrm{K}_{\text {location }}$ are in acceptable ranges for different time scales in this study. Maximum commission and omission errors observed in crops and grassland [27] were also noted in this study since complex changes in grassland and vineyard are difficult to simulate.

\section{Conclusion}

Studies of the temporal and spatial distribution of land cover change have become an important issue due to the rapid conversion of land cover and its impact on environment change. Time scale has a significant impact on prediction. Near perfect quantitative accuracy was achieved in all time scales but spatial accuracy varied with different time scales. High quantitative and location accuracy were found in forest prediction due to its large surface area, in which changes are relatively small and swapping does not impact prediction. Prediction of vineyard and grassland were difficult due to high swapping with one another and forest, and prediction of built area was complicated by the dramatic relative growth that increased in the recent time periods and the emergence of urban lots far from historic centers. Cell size and catchment area may also impact land cover change simulation and this is under study now.

\section{References}

1. Ahmed, B., Ahmed, R.: Modeling urban land cover growth dynamics using multi-temporal satellite images: A case study of Dhaka, Bangladesh. ISPRS International Journal of Geo-Information 1, 3-31 (2012), doi:10.3390/ijgi1010003

2. Álvarez-Martínez, J.M., Suárez-Seoane, S., Luis Calabuig, E.D.: Modelling the risk of land cover change from environmental and socio-economic drivers in heterogeneous and changing landscapes: The role of uncertainty. Landscape and Urban Planning 101, 108-119 (2011), doi:10.1016/j.landurbplan.2011.01.009

3. Araya, Y.H., Cabral, P.: Analysis and Modeling of Urban Land Cover Change in Setúbal and Sesimbra, Portugal. Remote Sensing 2, 1549-1563 (2010), doi:10.3390/rs2061549

4. Bohnet, I., Pert, P.L.: Pattern, drivers and impacts of urban growth- A study from Cairns, Queensland, Australia from 1952 to 2031. Landscape and Planning 97, 239-248 (2010), doi:10.1016/j.landurbplan.2010.06.007

5. Chaudhuri, G., Clarke, K.C.: Temporal accuracy in urban growth forecasting: A study using the SLEUTH model. Transactions in GIS 18, 302-320 (2014), doi:10.1111/tgis.12047

6. Chen, H., Pontius Jr., R.G.: Diagnostic tools to evaluate a spatial land change projection along a gradient of an explanatory variable. Landscape Ecology 25, 1319-1331 (2010), doi:10.1007/s10980-010-9519-5 
7. Dietzel, C., Clarke, K.: The effect of disaggregating land use categories in cellular automata model calibration and forecasting. Computers, Environment and Urban Systems 30, 78-101 (2006), doi:10.1016/j.compenvurbsys.2005.04.001

8. Eastman, J.R.: IDRISI Selva Help System. Clark Labs, Clark University, Worcester (2012)

9. Fox, D.M., Witz, E., Blanc, V., Soulié, C., Penalver-Navarro, M., Dervieux, A.: A case study of land cover change (1950-2003) and runoff in a Mediterranean catchment. Applied Geography 32, 810-821 (2012), doi:10.1016/j.apgeog.2011.07.007

10. Guan, D., Li, H., Inohae, T., Su, W., Nagaie, T., Hokao, K.: Modeling urban land use change by the integration of cellular automata and Markov model. Ecological Modelling 222, 3761-3772 (2011), doi:10.1016/j.ecolmodel.2011.09.009

11. He, C., Okada, N., Zhang, Q., Shi, P., Zhang, J.: Modeling urban expansion scenarios by coupling cellular automata model and system dynamic model in Beijing, China. Applied Geography 26, 323-345 (2006), doi:10.1016/j.apgeog.2006.09.006

12. He, C., Okada, N., Zhang, Q., Shi, P., Li, J.: Modelling dynamic urban expansion processes incorporating a potential model with cellular automata. Landscape and Urban Planning 86, 79-91 (2008), doi:10.1016/j.landurbplan.2007.12.010

13. Huang, Q., Cai, Y.: Simulation of land use change using GIS-based stochastic model: The case study of Shiqian County, Southwestern China. Stochastic Environment Research Risk Assessment 21, 419-426 (2007), doi:10.1007/s00477-006-0074-1

14. Jenerette, G.D., Wu, J.: Analysis and simulation of land -use change in the central Arizona Phonix region, USA. Landscape Ecology 16, 611-626 (2001)

15. Kamusoko, C., Aniya, M., Adi, B., Manjoro, M.: Rural sustainability under threat in Zimbabwe-Simulation of future land use/cover change in the Bindura district based on the Markov-cellular automata model. Applied Geography 29, 435-447 (2009), doi:10.1016/j.apgeog.2008.10.002

16. Khoi, D.D.: Spatial modeling of deforestation and land suitability assessment in the Tam Dao National Park region. University of Tsukuba, Vietnam. Ph. D. thesis (2011)

17. Lambin, E.F., et al.: The cause of land-use and land-cover change: moving beyond the myths. Global Environment Change 11, 261-269 (2001)

18. Li, X., Yeh, A.G.O.: Neural network based cellular automata for simulating multiple land use change using GIS. International Journal of Geographical Information Science 16, 323-343 (2002), doi: 10.108 0/13658810210137004

19. Mas, J.F., Pérez-Vega, A., Clarke, K.C.: Assessing simulated land use/cover maps using similarity and fragmentation indices. Ecological Complexity 11, 38-45 (2012), doi:10.1016/j.ecocom.2012.01.004

20. Mhangara, P.: Land use/ cover change modeling and land degradation assessment in the Keiskamma catchment using remote sensing and GIS. University of Nelson Mandela Met-ropolitan. Ph. D. thesis (2011)

21. Pérez-Vega, A., Mas, J.F., Ligmann-Zielinska, A.: Comparing two approaches to land use /cover change modeling and their implications for the assessment of biodiversity loss in a deciduous tropical forest. Environmenta Modelling \& Software 29, 11-23 (2012), doi:10.1016/j.envsoft.2011.09.011

22. Pontius Jr., R.G., Millones, M.: Death to Kappa: birth of quantity disagreement and allocation disagreement for accuracy assessment. International Journal of Remote Sensing 32, 4407-4429 (2011), doi:org/10.1080/01431161.2011.552923

23. Roy, H.G., Fox, D.M., Emsellem, K.: Spatial dynamics of land cover change in a Mediterranean catchment (1950-2008). Journal of Land use Science (2014) 
24. Sang, L., Zhang, C., Yang, J., Zhu, D., Yun, W.: Simulation of land use spatial pattern of towns and villages based on CA-Markov model. Mathematical and Modelling 54, 938-943 (2011), doi:10.1016/j.mcm.2010.11.019

25. Silva, T.S., Tanliani, P.R.A.: Environment planning in the medium littoral of the Rio Grand do Sul coastal plain - Southern Brazil: Elements for coastal management. Ocean and Coastal Management 59, 20-30 (2012), doi:10.1016/j.ocecoaman.2011.12.014

26. Tewolde, M.G., Cabral, P.: Urban sprawl analysis and modeling in Asmara, Eritrea. Remote Sensing 3, 2148-2165 (2011), doi:10.3390/rs3102148

27. Valdivieso, F.O., Sendra, J.B.: Application of GIS and remote sensing techniques in generation of land use scenarios for hydrological modeling. Journal of Hydrology 365, 256-263 (2010), doi:10.1016/j.jhydrol.2010.10.033

28. Verburg, P.H., de Koning, G.H.J., Kok, K., Veldkamp, A., Bouma, J.: A spatial explicit allocation procedure for modellling the pattern of land use change based upon actual land use. Ecological Modelling 116, 45-61 (1999)

29. Verburg, P.H., Schulp, C.J.E., Witte, N., Veldkamp, A.: Downscaling of land use change scenarios to assess the dynamics of European landscapes. Agriculture, Ecosystem and Environment 114, 39-56 (2006), doi:10.1016/j.agee.2005.11.024 